\title{
About mentees and mentors: what kind of advanced training should young scientists receive? - A personal reflection
}

\author{
Rüdiger E. Scharf ${ }^{1}$ \\ 1 Program in Cellular and Molecular Medicine, Boston Children's \\ Hospital, Harvard Medical School, Boston, MA, USA \\ Hämostaseologie 2020;40:379-381.
}

\begin{abstract}
Address for correspondence Rüdiger E. Scharf, MD, PhD, FAHA, Visiting Professor of Pediatrics, Harvard Medical School, Program in Cellular and Molecular Medicine, Boston Children's Hospital, Karp Family Research Laboratories, 1 Blackfan Circle, RB09211.1, Boston, MA 02115, USA (e-mail: ruediger.scharf@childrens.harvard.edu).
\end{abstract}

\author{
Summary \\ Keywords \\ - MD/PhD training \\ programs \\ - postdoctoral fellows \\ - mentoring \\ - good scientific \\ practice \\ - career planning \\ Zusammenfassung \\ Schlüsselwörter \\ - MD/PhD \\ Ausbildungs- \\ programme \\ - Nachwuchs- \\ wissen- \\ schaftler*innen \\ - Betreuung \\ - gute \\ wissenschaftliche \\ Praxis \\ - Karriereplanung
}

Comprehensive training of talented MD or PhD students and postdoctoral fellows is one of the essential requirements for a future career as an established investigator or even an outstanding scientist. Here, from personal experience, several relevant aspects are summarized including the high responsibility of the academic mentor. Specifically, the interaction of the mentor with fellows, the choice of the research project, and the impact of the mentor's personality on mentees are discussed.

Eine umfassende Ausbildung talentierter Doktoranden*innen und Nachwuchswissenschaftler*innen ist unerlässlich für eine künftige Karriere als etablierter Forscher oder erst recht als überragender Wissenschaftler. Aus persönlicher Erfahrung werden hier einige wichtige Kriterien dargestellt. Dazu zählt die hohe Verantwortung des akademischen Mentors. Insbesondere wird auf die Mentor-Schüler-Interaktion, die Wahl des Forschungsprojekts und auf die Entwicklung der Nachwuchswissenschaftler unter Einfluss der Persönlichkeit des Mentors eingegangen.

\section{Introduction}

Working with Dr. Stefano Barco, Mainz/Zurich, and closely interacting with postdoctoral fellows during my current stay at Boston Children's Hospital have stimulated me to think more deeply about the education of the new generation of scientists. Apart from instructions to improve practical and mental skills, including research planning and data analysis, what kind of training should young scientists receive?

To start with, we should ask the question "what are the essential characteristics of a true scientist?" A brief answer might be: "They are individuals with a driving force of curiosity about what makes 'things' work”. A more thorough and specific characterization would include that scientists must be endowed with patience, intelligence, endurance, enthusiasm and a keen and permanent desire to learn and to understand.

(c) 2020 Georg Thieme Verlag KG Stuttgart · New York
DOI https://doi.org/ 10.1055/a-1179-4057. ISSN 0720-9355. 


\section{The mentees}

Basic facts of 'nature' and life sciences are taught to young students during their academic education at universities with graduate programs. But how to become a successful or even outstanding scientist? If the saying is true that great scientists are born, not made, then every successful scientific career would be programmed by the individual genes. However, becoming an outstanding scientist is something that one can best learn from those who are making active contributions to science. Therefore, choosing the 'right' mentor within the 'right' environment is a crucial step that requires careful consideration. "Train with the best" is certainly an essential advice to students who are planning a scientific career. However, it is not that easy to follow and realize this advice. True role models of mentors are rare, and training of graduate, $\mathrm{MD}$, or $\mathrm{PhD}$ students and postdoctoral fellows can be an exhausting and stressful burden to academic teachers. Remarkably, there is a significant consistency among established scientists that those who later became the most successful and prominent representatives in their field had in fact outstanding mentors during postdoctoral training.

\section{Interaction of mentees and mentors}

Advanced training is a decisive stage of life of aspiring MD and $\mathrm{PhD}$ researchers or postdoctoral fellows. During this period, a pivotal turning point for their future career is taking place. Therefore, the young scientists should be eager to receive the best possible training. In this context, it is important to bear in mind that their activity in the laboratory is not primarily to augment the research program of the principle investigator but to increase their experience and to elaborate their skills. Therefore, special training programs are required to assure that at least some of the fellows are enabled to become outstanding scientists of the next generation. To bring this very much to the point: postdoctoral fellows should not be regarded as technicians who are working longer hours for less compensation.

Choosing the appropriate settings and targets for research is one of the most relevant abilities for aspiring researchers to learn. Therefore, the mentor should discuss alternative projects and approaches with the mentee who should have the option to delineate a proposed project. Students and fellows should be discouraged from working on high-risk, 'winner-take-all' experiments and projects. The mentor should inspire the mentee but, vice versa, the mentee must not be 'seduced' by the mentor's enthusiasm or ambition. Challenge and promotion as well as criticism and crediting by the mentor should be well-balanced.

Networking with fellows and established investigators from other laboratories, improving communication and presentation skills, and receiving advices or support for career planning are also relevant issues of training programs.

\section{Perspectives for mentees}

Given the fact that not all trainees of even the best graduate and postdoctoral programs succeed in science, it remains crucial to fellows to decide how they plan to spend their life. In fact, not everyone is suited for an academic research career. If this happens to be the case, it is better to find out about it sooner rather than later. The competition among trained postdocs who have completed their fellowship is enormously high. At Harvard, the rate of those who are accepted subsequently in an academic position is about $15 \%$. Thus, having completed postdoctoral training, the majority of fellows leaves laboratory science for careers in business, pharmaceutical industry, or research outside of universities. However, this choice should not be considered a failure either of the trainee or the program. More importantly, the mentees' experience allows them to make the choice that is more appropriate to them.

\section{The impact of mentors on mentees}

From a psychological perspective, it is nowadays generally accepted that most of our individual personality traits are firmly established in early childhood. In view of this, it may be interesting to observe the extent to which a scientific personality reflects the environment provided during academic education, specifically during postdoctoral training.

If the young scientist's mentor has a generous personality in sharing insights, tools and credit for discoveries, so will be the mentee. If the mentor is highly self-critical in evaluating his own scientific activities, the student will rather adopt the same approach and virtue. If the mentor has the personality of a pedantic bean counter, the young trainee may assume the same practice or become a meticulous nitpicker at best. And finally, a scientist who cuts corners, who is more concerned about personal glorification than about progress in science is at risk to generate the same kind of progeny among the fellows. These examples may be a little bit overdrawn. However, they illustrate the mentors' high responsibility towards their mentees.

\section{The mentors' responsibility towards mentees}

As academic teachers and scientists, we should be aware of the particular responsibility to MD and/or PhD students. Specifically, we should serve as good role models. This high demand to ourselves provides a profound basis of additional standards, so that the new generation of scientists will have the same virtues that we admire in science and research. These virtues include an open mind, as opposed to unthinking acceptance of authority or knowledge of what has already been learned and is thought to be true, permanent inquisitiveness, and, above all, honesty. These virtues will remain mandatory to unravel secrets of nature in health and disease.

To train talented young scientists and to prepare them today for leadership positions in the world of science of tomorrow is an essential and privileged task of academic mentors. 
Conflict of interest

None declared.

Acknowledgement

I am grateful to my former mentors, Prof. Volker Ullrich, Konstanz, and the late Prof. Ernst F. Lüscher, Berne, for their MD and postdoctoral training provided to me. I also remember with gratitude the late Prof. Ernst Beutler, La Jolla, with whom I could have inspiring discussions and who has been a real role model of a physician-scientist and academic mentor throughout his life. Funding of my research at Boston Children's Hospital by a GTH grant is also acknowledged. 